\title{
MAKANAN PENDAMPING ASI
}

\author{
Yulia Safitri* \\ Surel: mumunrieto@gmail.com
}

\begin{abstract}
The research objective was to determine the relationship of knowledge to the mother's attitude in providing complementary feeding in the village health center field weeds.This is a descriptive analytic study with cross sectional design. The sample was selected by simple random sampling of all mothers with babies aged 6-12 months who are 32 or older people. Primary data were collected using interviews and observation. The results showed that the relatively good knowledge of the respondents (56.2\%), the attitude of the respondents classified as moderate (65.6\%). There is a significant relationship between knowledge by providing complementary feeding (0.001), and significant relationship between attitudes to the provision of complementary feeding (0.001). It is recommended to health workers to be more routine counseling to mothers who have babies and approach local community leaders in order to help doing the counseling.
\end{abstract}

Keywords: Knowledge, Attitude, Mother, Giving complementary feeding breast milk (MP-ASI)

*Yulia Safitri, SST., M.Kes. Dosen Prodi D-III Kebidanan STIKes Flora Medan 


\section{PENDAHULUAN}

izi merupakan salah satu
faktor penting yang
menentukan kesehatan dan kesejahteraan manusia. Gizi seseorang dikatan baik apabila terdapat keseimbangan dan keserasian antara perkembangan fisik dan perkembangan mental orang tersebut (Hananto Wiryo, 2002). Terdapat kaitan yang sangat erat antara status gizi dan dengan konsumsi makanan.namun. Tingkat status gizi optimal akan tercapai apabila kebutuhan zat gizi optimal terpenuhi (Hananto Wiryo, 2002). Namun demikian perlu diketahui bahwa keadaan gizi seseorang dalam suatu masa bukan saja ditentukan oleh konsumsi zat gizi pada saat itu saja, tetapi lebih banyak ditentukan oleh konsumsi zat gizi pada masa yang telah lampau, bahkan jauh sebelum masa itu. ini berarti bahwa konsumsi zat gizi masa kanak-kanak memberi asupan terhadap status gizi setelah dewasa.

Penelitian WHO tahun 2001 tentang pemberian ASI eksklusif $(<4$ bulan) dari tahun 1995-2001 dibeberapa negara menunjukan kan bahwa negara kurang berkembang sebesar 37\%, negara berkembang sebesar 48\%, dan angka dunia sebesar $45 \%$.Hal ini menggambarkan masih rendah nya praktek pemberian MP-ASI dinegara-negara tersebut.

Sedangkan di Amerika Serikat survei yang dilakukan oleh Russ laboratories mother dan
NHANES-III tentang ibu yang memberikan ASI dan yang memberikan ASI eksklusif sampai bayi pada umur 6 bulan tahun 19712001 menggambarkan bahwa pada tahun 2001 ibu-ibu yang melahirkan di rumah sakit dan memberikan ASI pada bayi nya sebesar $69,5 \%$ dan diamti secara longitudinal, ibu-ibu yang memberikan ASI eksklusif sampai 6 bulan sebesar 32,5\% dari angka tersebut berarti $67,5 \%$ dari ibu-ibu yang memberikan ASI sudah melakukan praktek pemberian MPASI dini (Frances, et al, 2006).

$$
\text { Dalam Studi WHO di } 3
$$
negara bahwa ibu-ibu yang memberikan MP-ASI kepada bayi mereka pada usia 2-3 bulan di daerah pedesaan dan perkotaan menunjukan di Guatemala 52\% di daearah perkotaan dan $20 \%$ di daereah perdesaan sudah di beri MP-ASI, Di Zaire, $32 \%$ di perkotaan dan 55\% Perdesaan baik usia 2-3 bulan sudah di beri MP-ASI. Hasil studi WHO melalui Multisentre Growth Reference study (MGRS) yang diselengarakan antara tahun 19972003 di 6 Negara (Brazil, Ghana, India, Norwegia, Owan dan AS). Dengan sampul bayi 0-24 bulan (Baduta) di lewati kurva pertumbuhan, ASI eksklusif dan ibu tidak merokok di peroleh gambaran bahwa dari 1737 baduta 882 $(50,70 \%)$ diantara tetap di berikan ASI eksklusif sedang $855(49,30 \%)$ baduta sudah di berikan MP-ASI 
sebelum usia 6 bulan (WHO, 2006) Penelitian yang di lakukan oleh Ramachandran di daerah kumuh india tahun 1987 menyebutkan bahwa pemberian MP-ASI secara dini dapat mengakibatkan Under nutrition pada bayi yang dapat meningkatkan terjadi infeksi. Dengan meningkat nya resiko infeksi maka akan meningkat pula resiko kematian yang akan berdampak tinggi nya angka kematian bayi (AKB) (Nunghareni, 2009).

Sedangkan di Malaysia angka kematian hanya 41 per 100 ribu,Singapura 6 per 100 ribu, Thailand 44 per 100 ribu, dan Filiphina 170 per 100 ribu, Menurut Survei Demografi Kesehatan Indonesia 2002- 2003, angka kematian bayi (AKB) tercatat 35 per 1.000 kelahiran hidup. Data di badan pusat statistik menunjukan angka kematian ibu dan bayi diIndonesia tertinggi di Asia Tenggara, mendominasi lebih dari $75 \%$ total kematian anak dibawah 5 tahun.Di indonesia sendiri salah satu studi mengenai ASI atau makan pendamping ASI adalah studi yang di lakukan di 4 kabupaten di jawa timur (kediri, Blitar, Mojokerto dan pasuruan). Study ini menunjukan bahwa sebanyak lebih dari $80 \%$ ibu yang tidak memberikan ASI eksklusif 4 bulan dan telah memberikan makanan/minuman prelaktal dalam 3 hari pertama ke pada bayi nya umum nya berupa susu formula di jawa barat $26,2 \%$ dan jawa timur $67,4 \%$ sedangkan madu di jawa barat $25,8 \%$ dan jawa timur 15,3\% (Fikawati, 2003).

Studi MP-ASI tahun 1997 yang di lakukan di bogor,indramayu (jawa barat) purworejo (jawa tengah) jombang( jawa timur) Menunjukan bahwa antara $7-40 \%$, (rata-rata $21 \%$ ) ibu telah memberikan MP-ASI komersial (SUN NESTLE, MILNA) setiap hari pada bayi nya di bawah 5 bulan. Sedangkan dari Sumatra Utara Hasil Survei Ekonomi Nasional (Susenas) 2002 menunjukkan bahwa presentase ibu yang memberi makanan bayi terlalu dini kepada bayinya cukup tinggi, 32\% ibu memberikan makanan tambahan kepada bayinya ketika berumur 2-3 bulan, 69\% terhadap bayi yang berumur 4-5 bulan. Kondisi yang sama terdapat di Kecamatan Pandan Kabupaten Tapanuli Tengah sebanyak $51,15 \%$ dari 1.268 bayi sudah mendapat MP-ASI di bawah usia 6 bulan (Susenas, 2002). Untuk itu pemberian makanan tambahan, juga akan mengurangi produksi karena si anak menjadi jarang munyusu. Tujuan pemberian makanan tambahan sebagai penganti ASI agar anak cukup memperoleh kebutuhan energi, protein dan zat-zat gizi lain untuk tumbuh kembang secara normal. Meskipun anak telah diberi makanan tambahan,

\section{METODE PENELITIAN}

Jenis penelitian ini adalah penelitian survei bersifat deskriptif 
analitik dengan rancangan crosssectional (Notoatmodjo, 2010), yaitu untuk mengetahui hubungan pengetahuan dan prilaku ibu dengan pemberian MP-ASI pada bayi usia 6-12 bulan.

Populasi dalam penelitian ini adalah seluruh ibu yang mempunyai bayi usia 6-12 bulan di puskesmas Desa Lalang Medan sebanyak 540, dengan pertimbangan tertentu karna banyak nya populasi maka saya mengambil populasi satu kelurahan saja yaitu sebanyak 214 .

Sampel dalam penelitian ini adalah berjumlah 30 orang.

Analisa data yang digunakan dalam penelitian ini adalah (1) Analisa Univariat (2) Analisis Bivariat dengan menggunakan uji statistik paired sample t-test yaitu untuk melihat perbedaan sebelum dan sesudah perlakuan dengan menggunakan teknik komputerisasi yaitu program SPSS 16.0

\section{PEMBAHASAN}

Identitas Responden meliputi umur, suku, pendidikan, pekerjaan, penghasilan dan jumlah anak diuraikan sebagai berikut :

\section{Tabel 1 Distribusi Responden Menurut Karakteristik.}

\begin{tabular}{clcc}
\hline No & Karakteristik & n & \% \\
\hline 1 & Umur & & \\
& & 5 & 15.6 \\
& $<25$ Thn & & 2 \\
& & & 56.2 \\
& $25-30$ Thn & 18 & 5
\end{tabular}

$>30$ Tahun

2 Suku

$\begin{array}{lcc}\text { Aceh } & & 25.0 \\ & 8 & 0 \\ \text { Batak } & & 31.2 \\ & 10 & 5 \\ \text { Jawa } & & 28.1 \\ \text { Melayu } & 9 & 2 \\ \text { Pendidikan } & 3 & 9.37 \\ \text { SMP } & & \\ & 3 & 9.04 \\ \text { SMA } & & 18.0 \\ & 6 & 8 \\ \text { Diploma } & & 40.0 \\ & 13 & 6 \\ & & 31.0\end{array}$

4 Pekerjaan

$10 \quad 2$

IRT

Wiraswata

Pegawai Swasta

Pegawei negeri

5 Penghasilan

$<$ Rp. 750.000

Rp. 750.000 - Rp.

1.500 .000

$>1.500 .000$

6 Jumlah Anak

$\begin{array}{lcc} & & 56.0 \\ \text { Multipara (2-4 anak) } & 18 & 6 \\ \text { Grande multipara }>4 & & 40.0 \\ \text { anak } & 13 & 6 \\ & & 03.0 \\ \text { Primipara } & 1 & 1\end{array}$

Berdasarkan tabel di atas dapat diketahui bahwa didapatkan sebagian besar responden berada 
pada usia 25-30 tahun sebanyak 18 orang $(56,25 \%)$, sebagian besar responden bersuku batak sebanyak 10 orang $(31,25 \%)$, pendidikan responden sebagian besar adalah SMA yaitu 13 orang $(40,06 \%)$, sebagian besar responden bekerja sebagai pegawai negeri sebanyak 10 $(31,02 \%)$, penghasilan responden sebagian besar adalah Rp. 750.000 Rp. 1.500 .000 sebanyak 15 orang $(46,09 \%)$ dan sebagian besar responden memiliki anak multipara (2-4 anak) sebanyak 18 orang $(56,06)$.

\section{Tabel 2 Distribusi Pengetahuan dan Sikap Ibu dalam Pemberian MP-ASI}

\begin{tabular}{clcc}
\hline No & Karakteristik & N & \% \\
\hline 1 & Pengetahuan Ibu & & \\
& Baik & 18 & 56.02 \\
& Cukup & 14 & 43.08 \\
& Kurang & 0 & 00.00 \\
2 & Sikap Ibu & & \\
& Negatif & 21 & 65.06 \\
& Positif & 11 & 34.04
\end{tabular}

Berdasarkan tabel diatas dapat diketahui bahwa sebagian besar responden berpengetahuan baik yaitu sebanyak 18 orang (56.02\%) dan sebagian besar responden bersikap negatif yaitu sebanyak 21 orang $(65.06 \%)$.

\section{Analisa Bivariat}

1. Hubungan Pengetahuan dengan Sikap Ibu dalam Pemberian MP- ASI Pada Bayi Usia 6-12 Bulan Di Puskesmas Desa Lalang Medan

2.

Berdasarkan tabel diatas didapatkan hasil bahwa sebagian besar responden yang pengetahuan kategori baik sebanyak 18 responden $(56,2 \%)$, sedangkan sikap positif yaitu sebanyak 16 responden $(50,0 \%)$, dan katagori negatif berjumlah 2 responden $(6,2 \%)$.

Responden yang dengan kategori cukup sebanyak 14 responden $(43,8 \%)$, sebagian besar responden yang bersikap positif sebanyak 5 responden $(15,6 \%)$ responden yang katagori sikap negatif dalam pemberian MP-ASI sebanyak 9 responden $(28.1 \%)$.

\section{Hubungan Pengetahuan Dengan Sikap Ibu Dalam Pemberian MP-ASI Pada Bayi Usia 6-12 Bulan Di Puskesmas Desa Lalang Medan}

Hasil analisis tabel diatas dapat dilihat nilai koefisien korelasi antara Pengetahuan dan sikap ibu dalam pemberian MP-ASI di Puskesmas Desa Lalang kecamatan medan sunggal adalah sebesar - 555 dengan taraf signifikan0.001 yaitu $\mathrm{p}$ Value $<\alpha \quad(0,000<0,01)$, maka $\mathrm{H}_{\mathrm{a}}$ diterima $\mathrm{H}_{\mathrm{o}}$ ditolak. Artinya terdapat hubungan positif antara Pengetahuan dan sikap ibu dalam pemberian MP- 
Yulia Safitri, Makanan Pendamping ASI.... Hal.87 - 93

ASI di Puskesmas Desa Lalang kecamatan medan sunggal.

Tabel 3 Hubungan Pengetahuan dengan Sikap Ibu dalam Pemberian MPASI Pada Bayi Usia 6-12 Bulan Di Puskesmas Desa Lalang Medan

\begin{tabular}{lcccccc}
\hline & \multicolumn{7}{c}{ Sikap } \\
Pengetahuan & Positif & $\%$ & Negatif & $\%$ & Total & $\%$ \\
\hline \multirow{nyyyyyyy}{*}{ Baik } & 16 & 50.0 & 2 & 6.2 & 18 & 56.2 \\
Cukup & 5 & 15.6 & 9 & 28.1 & 14 & 43.8 \\
Kurang & 0 & 0.00 & 0 & 0.00 & 0 & 0.00 \\
\hline \multicolumn{1}{c}{ Total } & 21 & 65.6 & 11 & 34.4 & 32 & 100.00 \\
\hline
\end{tabular}

Tabel 4 Hubungan Pengetahuan Dengan Sikap Ibu Dalam Pemberian MPASI Pada Bayi Usia 6-12 Bulan Di Puskesmas Desa Lalang Medan

Correlations

\begin{tabular}{llrr}
\hline & & Pengetahuan & Sikap \\
\hline Spearman's rho Pengetahuan & $\begin{array}{l}\text { Correlation } \\
\text { Coefficient } \\
\text { Sig. (2-tailed) }\end{array}$ & 1.000 &. \\
& $\mathrm{~N}$ & 32 & .001 \\
\cline { 2 - 4 } Sikap & Correlation & 32 \\
\hline & Coefficient & $.555^{* *}$ & 1.000 \\
& Sig. (2-tailed) & .001 & \\
& $\mathrm{~N}$ & 32 & 32 \\
\hline
\end{tabular}

**. Correlation is significant at the 0.01 level (2-

tailed). 


\section{PENUTUP}

Berdasarkan hasi penelitian yang didapat dari 32 responden yang berdasarkan pengetahuan diperoleh data bahwa sebagian besar responden pengetahuan dengan baik sebanyak 18 responden $(56,02 \%)$, ibu yang pengetahuannya cukup dengan 14 responden $(43,08 \%)$. Sedangkan hasil penelitian berdasarkan sikap ibu dalam pemberian MP-ASI yaitu bersikap kategori positif 21 responden $(65.06 \%)$ dan kategori Negatif sebanyak 11 responden $(34.04 \%)$.

Dimana nilai koefisien korelasi yang didapat antara sikap ibu dalam pemberian makanan pendamping ASI adalah sebesar 0,555 dengan $p \quad$ Value $<\alpha$ $(0,000<0,01) \quad$ dengan taraf signifikansi $0,001 \%$ sehingga dapat disimpulkan bahwa terdapat Artinya terdapat hubungan positif antara Pengetahuan dan sikap ibu dalam pemberian MP-ASI di Puskesmas Desa Lalang kecamatan medan sunggal.

\section{DAFTAR PUSTAKA}

Notoatmodjo, Soekidjo. 2010). Metode Penelitian Kesehatan. Jakarta: Rineka Cipta.

Wiryo Hananto (2002). Peningkatan Gizi Bayi, Anak, Ibu Hamil, Dan menyusui dengan Baahan Makanan Lokal, Jakarta: CV Sagung Seto.
Kompas. 2009. 18 Persen Ibu Indonesia Memberi ASI Eksklusif. $\quad$ http://hqweb01 bkkbn.go.id/hqweb/pria/redaks i91.htm diakses pada 13 Juli 2010

SDKI 2007/2008 tentang Angka Kematian Bayi (AKB) kompas $2010 \quad$ http://webmail.jpkmonline.net/scr/login.php diakses pada 13 Agustus 2010

Hasrimayana. (2009) Jurnal Pemberian ASI Eksklusif. Diambil 21 Desember 2013 http://www.skripsipedia.com/2 011/01/

Setiawan. A (2009) Jurnal Pemberian MP-ASI FKM UI. Diambil tanggal 12 oktober 2013 http://www Pengetahuan Pemberian MP-ASI Pada Batita.

Sumut Pos. (2013). Medan Tertinggi Kasus Gizi Pada Bayi. Diambil tanggal 8 Oktober 2013 darihttp://www. sumutpos.co/2013/03/55020/m edan-tertinggi-kasus-Gizi.

Pratiwi. A (2009). Karya tulis Ilmiah MP-ASI. Diambil 19 Desember 2013. http://www.skripsipedia.com/2 011/01/Dinkes,2009. 